\title{
Professionalism, Personal Taste and Social Inclusion: Does it Matter What Clients Wear?
}

\author{
Authors: \\ Kirsty Pope \\ Lecturer in Occupational Therapy, University of Salford \\ MSc, BSc (Hons), ROT \\ Deborah Davys \\ Lecturer in Occupational Therapy, University of Salford \\ BSc (Hons), Dip COT, ROT, \\ Jackie Taylor \\ Senior Lecturer in Occupational Therapy, University of Salford \\ MSc, BSc (Hons), Dip COT, ROT
}

Category of Submission: Opinion Piece

Key Areas: Professional Development

Word count: 1546 (excluding abstract)

Please direct correspondence to:

Kirsty Pope/Deborah Davys

Directorate of Occupational Therapy

University of Salford

Allerton Building

M6 6PU

Telephone 0161295 2419/2869

Email k.h.pope@salford.ac.uk D.Davys@salford.ac.uk

Fax 01612952432 


\begin{abstract}
An earlier opinion piece considered the professional issues surrounding the occupational therapist's dress code within the work place (Davys et al 2006). This second paper considers the role of the occupational therapist when a client's choice of clothing may conflict with social expectations and negatively impact upon social inclusion. Three hypothetical cases that reflect clinical realities are presented, which serve as prompts for reflection upon informed choice, professional responsibilities and the therapeutic relationship. This paper concludes that there needs to be debate about the conflict between each of these areas and the concept of social inclusion.
\end{abstract}

\title{
Introduction
}

As occupational therapists, we often work with groups of people who have a disability which is linked to social exclusion which can be defined as a lack of full participation in all aspects of community life (Department of Work and Pensions 2006) .The need for social inclusion has been highlighted within government reports such as "Reaching out: An Action Plan on Social Exclusion ( Cabinet Office 2006 ) and "Working Together UK National Action Plan on Social Inclusion 2006-8 (Department of Work and Pensions 2006). These reports raise an interesting debate on informed choice and decision making that may support social inclusion and are relevant to the debate on client's choice of clothing and the role of the occupational therapist within this process. 


\section{Hypothetical scenarios and reflections from occupational therapy practice}

Stephen*.

When working in a learning disability service I felt shock and concern when I saw a young man walking down the street with two support workers wearing a T shirt which, in my opinion, had an offensive logo emblazoned across the back of it. This man, Stephen, had a significant degree of learning disability and behaviour that would be described as challenging. As such, the T shirt was not an item of clothing about which Stephen could have made a conscious decision. Staff reported at a later date that they were trying to "help" Stephen to be age appropriate and "trendy". They were going to the local pub which would be considered by the local community as an activity that enhances community presence and participation (Department of Health 2001). In my opinion however, it was likely that the combined effect of Stephen's disability and the offensive tshirt would serve to further alienate him from acceptance within the local community and make it more difficult for him to hold socially valued roles (Wolfensberger 1995).

\section{Mary*}

Mary and I were sitting together on the bus on our way to a luncheon club as part of her community rehabilitation. People turned to look at us. Not only did Mary conduct her conversations loudly, but she was also wearing a bright yellow flowery dress which she had proudly brought home from a charity shop a week before. I was part of the multidisciplinary team who had played a part in resettling 
Mary from a long stay psychiatric hospital, into a community-based hostel. It was the first time in fifteen years that Mary had had a home of her own.

Mary was 50 years old; she was very overweight and experienced psychotic symptoms. With her new-found freedom and independence she had found that she enjoyed scouring the local charity shops for brightly coloured girlish dresses (often several sizes too small). I reflected on whether it was ethical or an abuse of power (COT 2005), to try to persuade Mary to dress more discretely. My motives were sincere. From both a personal and professional perspective I didn't want Mary to attract unwelcome attention because I didn't want her to be laughed at and hurt, and I didn't want her to jeopardize the project as a whole, by making the hostel residents stand out as 'different' in the neighbourhood.

\section{John*}

John and I were sitting in the drop-in centre having a chat over a cup of coffee. John mentioned that whilst he was committed to becoming a woman he was struggling with people openly staring at him whilst he was out in public.

This conversation was interesting to me as it prompted several questions that would need careful consideration.

John was middle aged and had been referred to the psychiatrist by his GP due to his wish to have a sex change operation. Like most men in his position John had difficulty looking like a woman due to his masculine features e.g. large head, square jaw and, during the transition phase, difficulty with stubble. As an 
observer however, it was mine and the multidisciplinary team's opinion that people may well be staring at him not because of his transgender issues but due to how he had dressed himself. John would often wear what subjectively could be said to be too much make-up as well as often wearing mini skirts which, it could be argued, drew attention to his long and masculine looking legs.

This therefore raised a dilemma; is it the patient's right to dress as he chooses and should I remain completely client-centred by continuing along the path that the patient had chosen (Sumsion 2006), or should I help him to see that the way he is choosing to dress is possibly what is drawing attention to him, not the fact that he was transsexual.

\section{The dilemmas considered.}

These three scenarios are about different individuals with varying needs, but the themes of informed choice, professional responsibilities and the therapeutic relationship run throughout.

\section{Informed choice}

According to Sumsion (2006) informed choice is when the individual is aware of the variety of options open to them together with the benefits or risks involved. As occupational therapists, our Code of Ethics and Professional Conduct (COT $2005,2.1 .1)$ states that we need to support clients in making choices and decisions about their own health care and independence and that their choice should be respected even when this conflicts with our professional opinion. There is however, a crucial issue regarding understanding and choice in contrast 
to information and choice. The provision of information does not necessarily lead to understanding (Baker et al, 2004).

Both Stephen and Mary could have been given information related to the choices open to them. Due to his learning disability however, Stephen did not have the cognitive skills required to enable him to assimilate the information and therefore to understand the meaning of that information. Similarly, Mary could be described as having an impaired capacity to understand information due to her ability to make an informed choice having been diminished by 30 years of institutional living and a chronic mental health problem. The ability to act on the information given requires the individual to have an appreciation of the risks and benefits around that choice (Kuhn, 2002). It is important to note however that potential risks and benefits are much more difficult to define and evaluate with regard to the psychosocial context, which includes social identity and that which is culturally valued. In this arena, it is not possible to provide clear cut certainties about benefit or potential harm to clients (Godophilin, 2003). Not only is the problem solving process here more complex but it also raises the question of who should take the overall responsibility for making the final decision.

Occupational therapists strive to realise the ideal of client-centred practice where the client is at the centre of assessment and treatment (Sumsion 2006). This incorporates the principles of informed choice, but in some situations, clients may need to learn how to gain information, how to understand it, filter it and then use it to their best advantage. The concept of client-centred practice also suggests 
informed choice is an ongoing and evolving concept, not necessarily the client coming to a one off decision. It is a long term issue for both client and professional that requires the application of appropriate professional skills, such as counselling and the ability to provide information to a client in a culturally sensitive manner.

\section{Professional responsibilities}

Despite the complexity and uncertainties of scenarios such as those described within this article, occupational therapists have a professional responsibility to convey the predicted outcomes that a choice may lead to so that clients are able to make an informed choice wherever possible (COT 2005, Sumsion 2006). Due to his cognitive disability, Stephen was not in a position to make informed choices about his own clothes, nor the possible outcomes of choosing an offensive logo on his t-shirt. Staff had chosen this item of clothing for him in the belief that it was age appropriate and fashionable. Given that this man was at risk of being viewed in a negative way due to his disability (Atherton 2003), staff could be described as unprofessional and negligent in their duties by putting him in a situation which was likely to lead to further social devaluation.

\section{The therapeutic relationship}


Occupational therapists do not come to the therapeutic relationship as objective observers. Individual opinions, values and preferences are likely to impact upon the information presented, the way that it is presented and how it is interpreted by clients (Sumsion 2006). The information provided is also given within a social, political and cultural context, which could set limitations on an individual's expectations and social behaviour (Young et al, 2006). These points particularly relate to John who, whilst having the cognitive ability to understand the information provided did not necessarily understand the social, political and cultural contexts of being a woman. In order to fully enable John to understand the risks and benefits of each option available to him, the therapist has to be acutely aware of his or her own values and opinions.

\section{Debate}

Who then has the right to decide what are acceptable levels of understanding for whom and how might understanding be effectively developed for those expected to make choices? These are issues that require open debate and professional awareness of the prevailing social and cultural context in which an individual lives. 


\section{References}

Anonymised Reference (2006) Professionalism, Prejudice and Personal Taste:

Does it Matter What we Wear? British Journal of Occupational Therapy. XXX

Atherton, H. (2003) A History of Learning Disabilities in Learning Disabilities

Towards Inclusion. Ed. Gates,B. 4th Edition London: Churchill Livingstone. pp

41-60.

Cabinet Office (2006) Reaching out: An Action Plan on Social

Exclusion. London: HMSO

College of Occupational Therapists (2005) College of Occupational Therapists

Code of Ethics and Professional Conduct for Occupational Therapists. London:

College of Occupational Therapists.

Department of Health (2001) Valuing People a new strategy for learning disability for the 21 $\underline{\text { st }}$ century. London: The Stationary Office.

Department of Work and Pensions (2006) Working Together UK National Action Plan on Social Inclusion 2006-8 London: The Stationary Office.

Godolphin, W. (2003) The role of risk communication in shared decision making. British Medical Journal 327 pp692-693. 
Kuhn, L. (2002) Beyond informed choice: Infant feeding dilemmas for women in low-resource communities of high HIV prevalence. Social Dynamics 28 pp 1132 1154.

Sumsion,T. (2006) Client-Centred Practice in Occupational Therapy. A Guide to Implementation. London: Churchill Livingstone

Wolfensberger, W. (1995) The Principle of Normalization in Human Services.

Toronto: National Institute on Mental Retardation

Young, A., Carr, G., Hunt, R., McCracken, W., Skipp, A. \& Tattersall, H. (2006) Informed Choice and Deaf Children: Underpinning Concepts and Enduring Challenges. The Journal of Deaf Studies and Deaf Education. 11 (3) pp. 322336. 